\title{
Tindakan Sosial Tokoh Utama dalam Novel Kerumunan Terakhir Karya Okky Madasari
}

\author{
Susan Neni Triani', Zulfahita', Revi Jamelda ${ }^{3}$ \\ Program Studi Pendidikan Bahasa dan Sastra Indonesia, STKIP Singkawang, \\ E-mail: susannenitriani@gmail.com, zulfahita@yahoo.com, revi.jamela@gmail.com
}

Keywords : tindakan sosial, novel, sosiologi sastra.

\section{ABSTRACT}

Penelitian ini dilatarbelakangi oleh masyarakat yang menjalani kehidupan sehari-hari melalui tindakan sosial yang selalu manusia dituntut untuk berhubungan dengan orang lain. Karena hubungan inilah, maka tingkah laku seseorang sangat rentan untuk dipengaruhi. tujuan pelaksanaan penelitian ini adalah pendeskripsian tindakan tradisional, tindakan afeksi, tindakan instrumental, tindakan rasionalitas nilai dan implementasi terhadap pembelajaran bahasa Indonesia dalam novel Kerumunan Terakhir. Metode penelitian ini adalah metode deskriptif dengan bentuk penelitian kualitatif. Penelitian ini menggunakan pendekatan sosiologi sastra. Teknik analisis data menggunakan teknik analisis teks deskriptif. Pengecekan keabsahan data dilakukan dengan teknik Teknik menguji, keabsahan data, membaca kritis, kecukupan referensi, triangulasi. Berdasarkan hasil analisis terhadap novel Kerumunan Terakhir karya Okky Madasari. Maka dapat disimpulkan: (1) Peneliti menemukan 8 kutipan yang berhubungan dengan tindakan tradisional (2) Peneliti menemukan 30 kutipan yang berhubungan dengan tindakan afeksi (3) Peneliti menemukan 28 kutipan yang berhubungan dengan tindakan instrumental (4) Peneliti menemukan 19 kutipan yang berhubungan dengan tindakan rasionalitas nilai (5) Implementasi terhadap pembelajaran adalah pembelajaran tindakan tokoh utama dapat diterapkan pada siswa kelas XII dengan materi menganalisis teks novel baik melalui lisan maupun tulisan dan menggunakan metode tanya jawab dan diskusi. 


\section{PENDAHULUAN}

Sastra adalah sebuah karya fiksi, yang merupakan hasil kreasi berdasarkan imajinasi, emosi yang spontan dan diungkapkan melalui tulisan maupun lisan. Menurut (Wellek dkk, 2014:3) "Sastra adalah suatu kegiatan kreatif, sebuah karya seni". Jadi sastra merupakan hasil pekerjaan, pengalaman seni kreasi manusia yang tidak pernah lepas dari bahasa sebagai medium utamanya dari hasil tangan penulis yang berimajinasi tinggi.

Kehadiran sastra di tengah kehidupan masyarakat semangkin berkembang sebagai salah satu realitas sosial budaya. Sastra dan manusia saling berhubungan erat karena sastra sering bermulai dari persoalan dan permasalahan yang ada pada manusia di lingkungannya, kemudian dengan adanya imajinasi yang tinggi seorang pengarang tinggal menuangkan masalah-masalah yang dilihat, dihadapi disekitarnya menjadi sebuah karya sastra. Sebuah karya sastra bisa dikatakan memiliki nilai sastra jika di dalamnya terdapat kesepadanan antar isi dan bentuknya. Bentuk bahasa baik, benar dan indah serta susunan bahasanya bisa membuat seorang pembaca merasakan haru dan kagum. Isi dan bentuk sastra harus saling mengisi seperti dapat memberikan kesan yang mendalam bagi pembacanya sebagai perwujudan nilai-nilai karya seni. Karya sastra adalah sebuah hasil imajinasi yang diciptakan oleh seseorang pengarang dengan medium bahasa melalui tulisan atau lisan yang mengandung nilai estetika atau keindahan dari seni kreatif yang objeknya sendiri adalah manusia. Seni kreatif yang menggunakan bahasa dan semua segi kehidupan maka tidak saja merupakan suatu media untuk menyampaikan pikiran, perasaan, ide manusia. Sebagai karya kreatif sebuah sastra harus mampu menciptakan kreasi yang indah dan berusaha menyalurkan kebutuhan keindahan manusia. Karya sastra hadir sebagai wujud nyata imajinatif kreatif seorang sastrawan dengan proses yang berbeda antara penulis yang satu dengan penulis yang lain, terutama dalam menciptakan ciri fiksi yang ingin disampaikan penulis tersebut. Proses tersebut bersifat individualis artinya cara yang digunakan setiap penulis pasti berbeda-beda.

Manusia tidak lepas dari berbagai masalah kehidupan. Kehidupan yang kompleks tersebut mencakup hubungan manusia dengan tuhan, manusia dengan manusia, serta peristiwa dalam batin seseorang. Dalam rangka pemenuhan kebutuhan hidup, tentunya setiap orang akan berkomunikasi atau berhubungan dengan orang lain meskipun dari latar belakang etnis atau kelompok yang lain (Susanto \& Santoso, 2017). Kehidupan manusia digambarkan melalui tindakan sosial dalam menjalani kehidupan sehari-hari. Sebagai mahluk sosial, tentu saja manusia dituntut untuk selalu berhubungan dengan orang lain. Oleh karena hubungan inilah, maka tingkah laku seseorangpun sangat rentan untuk dipengaruhi oleh orang lain. Pengaruh itu bisa berasal dari keluarga, teman, dan masyarakat di lingkungan kita. Weber (dalam Anwar, 2013:144) menggungkapkan bahwa tidak semua tindakan manusia dapat dianggap sebagai tindakan sosial. Suatu tindakan hanya dapat disebut tindakan sosial apabila tindakan tersebut dilakukan dengan mempertimbangkan perilaku orang lain dan berorientasi pada perilaku orang lain. Karena tindakan sosial merupakan suatu tindakan individu yang diarahkan kepada orang lain dan memiliki arti baik bagi diri sendiri maupun bagi orang lain. Sebagai makhluk hidup senantiasa melakukan tindakan-tindakan untuk mencapai tujuan tertentu. Tindakan merupakan suatu perbuatan, perilaku, atau aksi yang dilakukan oleh manusia sepanjang hidupnya guna mencapai tujuan tertentu.

Novel merupakan uraian cerita dari berbagai besar kehidupan manusia yang ditokohkan dalam cerita yang di dalamnya terdapat berbagai jenis masalah yang harus dihadapi oleh tokoh tersebut. Masalahmasalah yang diuraikan atau ditulis di dalam novel bukan hanya terbatas pada cerita dalam dunia fiksi saja, namun ada kemungkinan juga banyak terdapat pada kehidupan yang ada di tengah-tengah masyarakat. Novel yang dipilih dalam penelitian ini adalah novel Kerumunan Terakhir karya Okky Madasari. Disajikan dengan bahasa yang mengalir sederhana dan mudah dipahami, novel ini memberikan pelajaran tentang arti keluarga. Kelebihan novel Kerumunan Terakhir terletak pada ceritanya yakni tentang kehidupan sebuah keluarga yang tidak harmonis, penuh dengan perjuangan seorang anak lelaki yang ingin membalaskan sakit hati ibunya kepada ayahnya yang suka gonta-ganti pasangan, dan memandang tugas suami hanya untuk memberi nafkah, tanpa memikirkan perasaan istri dan anak-anaknya yang seharusnya ia bimbing dan ia sayangi. Dengan teknologi yang semangkin 
canggih bisa membantu atau memudahkan sang anak untuk membalaskan dendam kepada ayahnya yang gila akan jabatan dan kepuasan. Novel ini penuh dengan inspirasi dimana seorang anak yang menyayangi ibunya sehingga harus melakukan tindakan yang kasar dan harus menjatuhkan jabatan yang diraih oleh ayahnya demi untuk menuntut keadilan bagi ibunya yang sudah disia-siakan oleh ayahnya.

Penelitian ini menggunakan pendekatan sosiologi sastra untuk menemukan tindakan yang ada di dalam novel Kerumunan Terakhir tersebut. Pendekatan sosiologi sastra dilatarbelakangi oleh fakta bahwa keberadaan karya sastra tidak dapat dari realita yang terjadi dalam kehidupan masyarakat. Dalam pendekatan ini, yang menjadi sasarannya adalah kehidupan seseorang dalam berinteraksi dengan lingkungan sosial dan juga diikuti oleh gejala-gejala yang terdapat dalam kehidupan masyarakat. Dikaitkan dengan hal tersebut, maka sosiologi sastra ini mengkaji aspek sosial seperti tindakan sosial di masyarakat. Seperti yang akan penulis lakukan yaitu meneliti tindakan sosial dalam novel Kerumunan Terakhir dan memaparkanya kepada pembaca agar mereka dapat memanfaatkanya dalam menjalani kehidupan ini.

Permasalahan yang terasa dalam novel Kerumunan Terakhir yaitu pada tokoh utama serta kejadiankejadian yang dialami yang berhubungan dengan tindakan sosial tokoh utama, tokoh utama dalam novel ini yakni Jaya. Novel Kerumunan Terakhir ini sangat banyak terdapat tindakan-tindakan sosial yang di perlihatkan oleh tokoh utama lewat kehidupan keseharianya dalam bermasyarakat. Oleh karena itu, penulis tertarik untuk mengkaji lebih dalam mengenai bentuk tindakan sosial karena suatu tindakan individu yang diarahkan pada orang lain dan memiliki arti baik bagi diri sendiri maupun orang lain. Penulis mengkaji Berdasarkan empat tipe tindakan sosia menurut teori Weber yaitu pertama tindakan tradisional, kedua tindakan afeksi, ketiga tindakan instrumental, dan keempat tindakan rasionalitas nilai.

Penelitian mengenai tindakan sosial tokoh utama memiliki hubungan dengan sastra khususnya dalam pelajaran sastra di sekolah, jika dikaitkan dan dihubungakan dengan pelajaran di sekolah, maka hubungan penelitian ini terdapat dalam Kurikulum 2013 (K13) tingkat SMA pada kelas/semester XII/II, dengan Kompetensi Dasar (KD) 3.3 menganalisis teks novel baik melalaui lisan maupun tulisan. 4.3 menyunting teks novel sesuai dengan struktur dan kaidah teks baik secara lisan maupun tulisan.

Berdasarkan latar belakang di atas, penulis tertarik untuk mengadakan analisis guna mengungkapkan tindakkan sosial tokoh utama dalam novel Kerumunan Terakhir karya Okky Madasari dengan judul "Tindakan Sosial Tokoh Utama dalam Novel Kerumunan Terakhir Karya Okky Madasari". Penulis berharap setelah peserta didik membaca penelitian tentang novel Kerumunan Terakhir Karya Okky Madasari ini, peserta didik mendapat pengetahuan tentang karya sastra sebagai bahan ajar dan bisa memahami serta menghayati sebuah karya sastra terutama tentang tindakan sosial tokoh utama dalam sebuah novel.

\section{METODE PENELITIAN}

Metode yang digunakan peneliti pada penelitian ini adalah metode deskriptif. Menurut Moleong (2017:11) menyatakan bahwa "data yang dikumpulkan dalam metode deskriptif adalah berupa katakata, gambar, dan bukan angka-angka". Hal itu disebapkan oleh adanya penerapkan metode kualitatif. Dengan Bentuk penelitian yang digunakan adalah bentuk kualitatif.

Pendekatan yang digunakan dalam rancangan penelitian ini adalah pendekatan sosiologi sastra, yaitu pendekatan dengan menganalisis kehidupan manusia dalam bermasyarakat. Mulyana (dalam Siswantoro 2016:47) mengatakan bahwa istilah lain yang identik dengan pendekatan adalah perspektif, kerangka konseptual, kerangka pemikiran, staretegi intelektual, paradigma, dan teknik interpretasi. Pendekatan sosioloigi sastra memiliki keterkaitan dengan novel. Sosiologi merupakan ilmu dalam mengkaji masyarakat dan dalam cerita novel juga tidak lepas dari pristiwa yang ada di lingkungan sosial serta gejala-gejala yang terjadi di dalam masyarakat adanya persamaan tersebut 
maka dapat meyakinkan bahwa pendekatan sosiologi sastra cocok digunakan dalam menulis novel.

Data dalam penelitian ini adalah berupa kutipan-kutipan atau kalimat dalam novel Kerumunan Terakhir Karya Okky Madasari yang merupakan objek penelitian. Kutipan yang menjadi data yaitu berupa kata, frasa, dan kalimat. Teknik pengumpulan data menggunakan studi dokumenter. Moleong, (2017:217) mengatakan Dokumen sudah lama digunakan dalam penelitian sebagai sumber data, karena dalam banyak hal dokumen sebagai sumber data dimanfaatkan untuk menguji, menafsirkan, bahkan untuk meramalkan. Berdasarkan dokumen peneliti mengumpulkan data terpilih melalui kegiatan membaca. Dikatakan data terpilih karena data tersebut harus mampu memberikan informasi sesuai dengan permasalahan yang diajukan peneliti. Alat pengumpul data pada penelitian ini yaitu penulis yang berperan sebagai instrumen kunci dalam perencanaan, pelaksanaan, sampai pengumpulan data. Alat bantu yang digunakan penulis adalah kartu catatan dan alat tulis untuk mengumpulkan data yang diperlukan. Pencatatan ini bertujuan untuk mendapatkan informasi yang mendukung analisis dan interpretasi data.

Teknik pemeriksaan keabsahan data Menguji keabsahan data dalam upaya mengetahui data yang diperoleh benar atau tidak, maka dilakukan pengecekan data. Menurut Miles dan Humberman (dalam Siswantoro, 2016:79) mengatakan bahwa Verification atau pengabsahan adalah arti atau makna yang muncul dari data harus diuji untuk memperoleh ketepercayaan, kekuatan dan kesesuaian, itulah validitas. Moleong (2017:329-330) mengatakan bahwa ketekunan pengamatan bermaksud menemukan ciri-ciri dan unsur-unsur dalam situasi yang sangat relevan dengan persoalan atau isu yang sedang dicari dan kemudian memusatkan diri pada hal-hal tersebut secara rinci. Dalam hal ini penulis harus teliti dan kritis dalam mengkaji data. Tringulasi Adalah teknik pemeriksaan keabsahan data yang dimanfaatkan sesuai yang lain di luar data itu untuk keperluan pengecekan atau sebagai banding terhadap data itu. Sugiyono (2015:369) mengatakan tringulasi dalam pengujian kredibilitas ini diartikan sebagai pengecekan data dari berbagai sumber dengan berbagai cara, dan berbagai waktu. Tujuan dilakukan tringulasi oleh penulis adalah untuk memastikan data memiliki keakuratan. Usaha yang dilakukan dalam memahami kecakupan referensial adalah dengan mencari, membaca, menelaah sumber-sumber yang relevan dengan masalah penelitian.

\section{HASIL PENELITIAN}

\section{HASIL DAN PEMBAHASAN}

Pada novel Kerumunan Terakhir ditemukan beberapa hasil penelitian yang sesuai dengan focus penelitian meliputi (1) tindakan tradisional, (2) tindakan afeksi, (3) tindakan instrumental, (4) tindakan rasionalitas nilai.

Tindakan Tradisional

Tindakan tradisional adalah Tindakan tradisional adalah tindakan sosial yang dilakukan oleh seseorang karena mengikuti tradisi atau kebiasaan yang sudah diajarkan secara turun-temurun dan telah baku serta tidak dapat diubah kembali. Jadi tindakan ini tidak melalui perencanaan yang sadar terlebih dahulu, baik dari cara maupun tujuannya. Karena mereka mengulanginya dari kebiasaan yang sudah dilakukan secara turun-temurun. Tindakan semacam ini adalah tindakan warisan yang diturunkan dari generasi yang lalu atau berlaku secara turun temurun untuk generasi berikutnya.

Mengumpulkan kayu bakar untuk memasak

"Simbah yang matanya buta sebelah mengajarku masuk hutan. Ia mengumpulkan kayu untuk memasak, sedangkan aku menembak burung dengan ketepel. Sibah juga membawa ku ke sungai besar. Di situ aku berenang, meloncat dari jembatan langsung ke dalam sungai (Madasari, 2017:23).”

Kutipan di atas menceritakan Simbah yang hidup di daerah perdesaan jauh dari riuh kota mengajari Jaya masuk ke hutan. Simbah mengumpulkan kayu untuk memasak, sedangkan Jaya menembak burung dengan ketepel. Simbah juga membawa Jaya ke sungai besar. Di sungai Jaya bisa berenang, meloncat dari jembatan hingga langsung ke air sungai. Tindakan yang dilakukan oleh simbah menandakan adanya tindakan tradisional. Hal ini dapat dibuktikan dari latar belakang kehidupan yang sangat menonjol dalam kebiasan pola hidup yang diterapkan oleh Simbah, seperti pada kegiatan mengumpulkan kayu untuk memasak yang dilakukan Simbah dan akan terus Simbah ulangi dari apa yang dia lakukan. Mengumpulkan kayu bakar hanya dilakukan di zaman dahulu yang memang belum mengenal adanya kompor. Untuk saat ini mengumpulkan kayu bakar sudah jarang dan mungkin sudah tidak ada lagi. Karena masyarakat sekarang sudah hampir rata-rata menggunakan kompor. 
Adapun tindakan tradisional yang ditunjukan oleh tokoh dalam novel tersebut memiliki keterkaitan sosial dengan lingkungan asli masyarakat.

Menembak burung dengan ketepel

"Simbah yang matanya buta sebelah mengajarku masuk hutan. Ia mengumpulkan kayu untuk memasak, sedangkan aku menembak burung dengan ketepel. Sibah juga membawa ku ke sungai besar. Di situ aku berenang, meloncat dari jembatan langsung ke dalam sungai (Madasari, 2017:23).”

Kutipan di atas menceritakan Simbah dengan matanya yang buta sebelah menagajari jaya masuk kehutan. Simbah mengumpulkan kayu bakar sedangkan Jaya menembak burung menggunakan ketepel. Simbah juga membawa Jaya ke sungai besar. Di sungai besar itu Jaya bisa berenang, meloncat dari jembatan yang tinggi hingga jatuh ke air sungai. Tindakan yang dilakukan oleh tokoh di atas menandakan adanya tindakan tradisional. Hal ini dapat dibuktikan dari latar belakang kehidupan yang sangat menonjol dalam kebiasan pola hidup yang diterapkan oleh Simbah dan Jaya, seperti pada kegiatan atau tindakan yang dilakukan Jaya dengan menembak burung dengan ketepel. Tindakan menembak burung oleh anak-anak dengan menggunakan ketepel sudah jarang kita temukan disaat ini. Kehadiran alat-alat yang cangih disaat ini membuat alat-alat yang kerap digunakan di zaman dahulu pelan-pelah hilang dan mulai dilupakan oleh masyarakat sekarang. Adapun tindakan tradisional yang ditunjukan oleh tokoh dalam novel tersebut memiliki keterkaitan sosial dengan lingkungan asli masyarakat. Bersemedi

"Saat aku bermain-main, Simbah duduk di gardu kecil sambil memejamkan mata dan mulutnya komat-kamit. Sibah sedang bersemedi. Setelah bersemedi ia menyapu wilayah puncak itu dengan sapu lidi yang dibawanya, membawa pulang sampah yang berserakan, ranting, dan daun-daun kering (Madasari, 2017:23).”

Kutipan di atas menceritakan tentang tindakan yang dilakukan Simbah saat Jaya sedang bermaian. Simbah melakukan ritual sebagai juru kunci di Suroloyo. Simbah tidak pernah lupa melakukan semedi di gardu kecil dengan mata tertutup dan mulutnya yang komat-kamit. Setelah selesai bersemedi Simbah melanjutkan dengan menyapu puncak Suroloyo dengan sapu lidi. Sampah yang berserakan, ranting, dan daun-daun dikumpulkan dan dibawa pulang oleh simbah.

Tindakan yang dilakukan oleh tokoh di atas menandakan adanya tindakan tradisional. Hal ini dapat dibuktikan dari latar belakang kehidupan yang sangat menonjol dalam kebiasan pola hidup yang diterapkan oleh Simbah, seperti pada kegiatan atau tindakan yang dilakukan Simbah keseharian hanya dihabiskan untuk terus mengulangi apa yang sudah ia lakukan setiap harinya seperti bersemedi dan membersihkan puncak Suroloyo. Tindakan bersemedi adalah tindakan yang sanggat kerap dilakukan di zaman dahulu karena masyarakat yang masih percaya akan kekuatan gaib. Tapi untuk saat ini tindakan bersemedi sudah jarang atau tidak lagi ditemukan karena masyarakat percaya akan iman dan agama yang akui masing-masih. Adapun tindakan tradisional yang ditunjukan oleh tokoh dalam novel tersebut memiliki keterkaitan sosial dengan lingkungan asli masyarakat.

Pakaian dan makanan saat pernikahan

"Simbah memberitahuku hari baik untuk menikah. Ia senang sekali saat tahu aku dan Maera akan menikah di puncak Suroloyo dengan Simbah yang menikahkan. Satu minggu sebelum kami menikah Simbah sudah berpuasa dan mengumpulkan kembang melati yang akan dironce untuk hiasan di rambut Maera. Simbah juga membuat jadah, bubur sumsum, dan dawet. Kami tak mengundang siapasiapa. Tapi kata Simbah, tamu akan banyak. Tamu-tamu yang tak bias dilihat oleh orang seperti aku dan Maera. Aku merinding sebentar lalu malah tertawa (Madasari, 2017:353).”

Kutipan diatas menceritakan tentang Jaya yang akan menikah. Simbah sangat senang ketika mengetahui Jaya akan menikah di puncak Suroloyo dan Simbah yang akan menikahi mereka. Simbah memberi tahu jaya hari terbaik untuk menikah. Seminggu sebelum Jaya menikah Simbah sudah berpuasa untuk menyiapi pernikahian Jaya dan simbah yang akan menikahinya. Saat berpuasa Simbah mengumpulkan bunga melati yang akan dironceng untuk hiasan rambut pengantin perempuan yaitu Maera. Simbah juga membuat jadah atau kue tradisi jawa yang terbuat dari beras ketan yang dikukus kemudian ditumbuk, bubur sum-sum dan dawet atau minuman khas jawa yang terbuat dari tepung beras atau tepung ketan dicampur gula merah dan santan. Pernikahan Jaya tidak mengundang siapasiapa. Tapi Simbah mengundang tamu-tamunya yang tak bisa terlihat atau yang berasal dari alam gaib. Tindakan yang dilakukan oleh tokoh di atas menandakan adanya tindakan tradisional. Hal ini dapat dibuktikan dari latar belakang kehidupan yang sangat menonjol dalam kebiasan pola hidup yang diterapkan oleh Simbah di puncak Suroloyo, seperti pada kegiatan atau tindakan yang dilakukan Simbah pada saat pernikahan Jaya yang membuat jadah, bubur sum-sum dan dawet. Tindakan dengan membuat makanan seperti jadah, bubur sum-sum dan dawet saat pernikahan sudah tidak lagi dilakukan masyarakat sekarang saat perkawinan. Meskipun dulu kerap dilakukan oleh masyarakat setempan kini dengan perkembangan zaman yang begitu pesat pelahan-lahan makanan khas daerah itu 
di tinggalkan. Adapun tindakan tradisional yang ditunjukan oleh tokoh dalam novel tersebut memiliki keterkaitan sosial dengan lingkungan asli masyarakat.

Tamu yang tidak bisa terlihat

"Simbah memberitahuku hari baik untuk menikah. Ia senang sekali saat tahu aku dan Maera akan menikah di puncak Suroloyo dengan Simbah yang menikahkan. Satu minggu sebelum kami menikah Simbah sudah berpuasa dan mengumpulkan kembang melati yang akan dironce untuk hiasan di rambut Maera. Simbah juga membuat jadah, bubur sumsum, dan dawet. Kami tak mengundang siapasiapa. Tapi kata Simbah, tamu akan banyak. Tamu-tamu yang tak bias dilihat oleh orang seperti aku dan Maera. Aku merinding sebentar lalu malah tertawa (Madasari, 2017:353)."

Kutipan di atas menceritakan tentang Jaya yang akan menikah. Simbah sangat senang ketika mengetahui Jaya akan menikah di puncak Suroloyo dan Simbah yang akan menikahi mereka. Simbah memberi tahu jaya hari terbaik untuk menikah. Seminggu sebelum Jaya menikah Simbah sudah berpuasa untuk menyiapi pernikahian Jaya dan simbah yang akan menikahinya. Saat berpuasa Simbah mengumpulkan bunga melati yang akan dironceng untuk hiasan rambut pengantin perempuan yaitu Maera. Simbah juga membuat jadah, bubur sum-sum dan dawet atau minuman khas jawa yang terbuat dari tepung beras atau tepung ketan dicampur gula merah dan santan. Pernikahan Jaya tidak mengundang siapa-siapa. Tapi Simbah mengundang tamu-tamunya yang tak bisa terlihat atau yang berasal dari alam gaib. Tindakan yang dilakukan oleh tokoh di atas menandakan adanya tindakan tradisional. Hal ini dapat dibuktikan dari latar belakang kehidupan yang sangat menonjol dalam kebiasan pola hidup yang diterapkan oleh Simbah di puncak Suroloyo, seperti pada kegiatan atau tindakan yang dilakukan Simbah dengan mengundang tamu-tamu dari alam gaib. Tindakan tersubut memang kerap dilakukan oleh masyarakat dahulu yang memang percaya akan adanya mahklip gaib. Untuk masyarakat saat ini tindakan tersebut sudah jarang bahkan sudah tidak lagi dilakukan oleh masyarakat yang modern. Yang tidak percaya lagi akan adanya mahkluk-mahkluk gaib. Adapun tindakan tradisional yang ditunjukan oleh tokoh dalam novel tersebut memiliki keterkaitan sosial dengan lingkungan asli masyarakat.

Tindakan Afeksi

Tindakan afeksi adalah tindakan yang dipengaruhi oleh emosi seseorang tidak melalui pertimbangan yang sadar tindakan ini tercipta dengan spontan karena pengaruh perasaan seseorang. Tindakan afeksi tergambar dari beberapa tindakan seperti cinta, gembira, marah dan takut. Tindakan afeksi memang terjadi begitu saja tanpa di sadari oleh individu itu sendiri.

Menangis

"Aku dijemput dan kembali hidup serumah dengan Bapak dan Ibu, juga ketiga adikku. Betapapun aku merindukan orangtuaku, aku menangis histeris saat mereka hendak membawaku pergi dari rumah Simbah. Aku memeluk tubuh Simbah erat-erat, tak mau di pisahkan darinya (Madasari, 2017:21)."

Kutipan di atas menceritakan kedekatan Jaya dengan Simah, tempat yang Jaya merasa nyaman dan bebas dari atauran ibunya. Saat Bapaknya kembali setelah menyelesaikan pendidikanya Jaya kembali dijemput dan dibawa pulang kerumah bersama Bapak, Ibu dan ketiga adiknya. Jaya merasa berat hati meninggalkan Simbahnya dan temapat Suroloyo. Pelukan erat pada tubuh Simbah tanda Jaya tidak mau pergi dari rumah Simbah. Meskipun Jaya rindu pada orang tuanya yang kerap Jaya rasakan namam berpisah dengan Simbahnya tak mampu untuk membuat Jaya menahan air matanya. Jaya menangis sekeras-kerasnya. Agar Simbahnya tau bahwa Jaya tidak mau berpisah dari dirinya.Tindakan yang dilakukan oleh tokoh di atas menandakan adanya tindakan afeksi. Hal ini dapat dibuktikan dari tindakan yang terjadi secara spontan oleh individu dan tidak disadarinya. Seperti yang dilakukan oleh Jaya dengan menangis histeris. Karena perasaannya yang benar-benar sedih. Seperti yang kita tahu bahwa laki-laki jarang sekali menangis sosok yang kuat dalam menyembunyikan segala kesedihan. Tapi saat dia harus meningalkan orang yang disayang sekuat apa pun dia menyembunyikan perasaanya maka secara tidak sadar dia akan menangis dan meneluarkan suara yang sekeras-kerasnya. Adapun tindakan afeksi yang ditunjukan oleh tokoh utama dalam novel tersebut memiliki keterkaitan sosial dengan lingkungan asli masyarakat. Menangis adalah tindakan yang lumrah bahkan semua kita pernah melakukannya. 


\section{Tertawa}

“Terus mau apa aku kalau sudah jadi manusia zaman baru?" Aku pun jadi ingin menggodanya.

"Ya kamu harus berpikir untuk masa depan dong! Manusia jaman baru itu tidak lagi hidup untuk masa lalu. Kamu harus maju. Bersaing dengan banyak orang, jadi pemenang. Jalan pertama sudah jelas cari kerja di Jakarta!"

"Hahaha....." aku tertawa lepas mendengar kata-katanya. "Itu sih justru pikiran orang kuno! (Madasari, 2017:81)."

kutipan di atas menceritakan tentang Jaya yang di suruh kekasihnya membuat email untuk mencari atau melamar kerja. Jaya harus menjadi manusia yang hidup di zaman baru yang berpikiri untuk masa depan dan melupakan masa lalu. Dengan Jaya harus maju, bersaing dengan banyak orang dan menjadi pemenangnya. Caranya dengan mencari kerja di Jakarta. Jaya tertawa lepas mendengar kata-kata kekasihnya. dan Jaya berpikir apa yang dikatakan oleh kekasihnya malah justru pola pikir orang kuno. Tindakan yang dilakukan oleh Jaya menandakan adanya tindakan afeksi. Hal ini dapat dibuktikan dari tindakan yang terjadi secara spontan oleh individu dan tidak disadarinya. Tindakan yang dilakukan Jaya seperti tertawa menendengar perkataan kekasihnya yang menyuruh Jaya menjadi manusia baru. Tindakan tertawa terjadi secara spontan tanpa seseorang sadari. tertawa bisa terjadi ketika seseorang merasa gembira dan mengingat kekonyolan atau kenaifan seseorang. Adapun tindakan afeksi yang ditunjukan oleh tokoh dalam novel tersebut memiliki keterkaitan sosial dengan lingkungan asli masyarakat. Tertawa adalah bentuk dari kegembiraan. Mulai dari anak kecil samapi orang tua semua melakukanya.

Marah

"Lagi-lagi aku kehilangan kesempatan. Kemarahanku pada orang-orang yang berdemonstrasi di depanku semangkin memucak. Aku terus-merus menekan klakson dengan kasar walaupun sama sekali tak mengubah apa-apa.

“Asu! Asuuu...! (Madasari, 2017:41)."

Kutipan di atas menceritakan Jaya yang sedang mengalami kemacetan karena orang-orang sedang demo. Sehingga Jaya tidak bisa lewat untuk mengantar Maera pulang . Karena jalan yang begitu padat. Serta Jaya kehilangan kesempatan untuk Mengantar Maera pulang wanita yang baru ia dekati dan ingin ia jadikan pacar. Kemacetan itu benar-benar membuat Jaya Marah. Jaya marah karena orangorang yang menyebabkan jalan itu macet. Sehingga ia terus-menerus menekan klakson motornya yang tidak mengubah jalan itu menjadi tidak macet lagi. Jaya merasa sangat kesal hingga mengeluarkan kata-kata kasar seperti Asu..(Anjing) berkali-kali. Tindakan yang dilakukan oleh Jaya menandakan adanya tindakan afeksi. Hal ini dapat dibuktikan dari tindakan yang terjadi secara spontan oleh individu dan tidak disadarinya, seperti yang Jaya lakukan. Dia marah kepada orang yang berdemo hingga membuat jalan macet. Hal itu terlihat dari Jaya yang menekan klakson motor terus-menerus di dalam tengah kemacetan dan karena kesalnya sampai-sampai Jaya mengeluarkan kata-kata yang kasar. Tindakan Jaya tersebut didasarkan atas emosi dan tampa disadari karena merasa kesal. Adapun tindakan afeksi yang ditunjukan oleh tokoh dalam novel tersebut memiliki keterkaitan sosial dengan lingkungan asli masyarakat. Marah pernah di rasakan semua orang.

Tindakan Instrumental

Tindakan instrumental meliputi pertimbangan dan pilihan yang sadar yang berhubungan dengan tujuan tindakan dan alat yang dipergunakan untuk mencapainya. Individu selalu memiliki tujuan yang beagam dari setiap hal yang diinginkan, maka individu dituntut untuk memilih. Dan untuk memenuhi tujuan itu, individu harus memiliki alat yang mendukung. Disini maksudnya sebelum seseorang melakukan suatu tindakan sosial seseorang itu sadar akan apa yang ia lakukan dan sadar tujuan dari tindakanya.

Dendam

"Aku memulai hidup baruku dengan nama baru: Matajaya, sebagai Matajaya, aku bias bebas bercerita tentang apa aja dan melakukan apa saja. Termasuk membalas dendam ku pada Bapak (Madasari, 2017:13).” 
Kutipan di atas menceritakan Jaya yang memulai hidup barunya dengan membuat akun faceboot dan twiter dengan nama Mayajaya. Dengan nama barunya Jaya bisa bebas bercerita dan bebas melakukan apa saja tampa ada yang tahu. Termasuk membalas Jaya kepada Bapaknya yang telah menyakiti Ibunya. Tindakan yang dilakukan oleh Jaya menandakan adanya tindakan instrumental. Hal ini dapat dibuktikan dengan sebelum melakukan suatu tindakan seseorang sadar akan apa yang dilakukan dan sadar akan tujuan dari tindakanya. Seperti tindakan Jaya yang memulai hidup barunya tujuan kedepan dari tindakan Jaya adalah untuk membalaskan dendam kepada Bapaknya yang telah menyakiti hati ibunya. Adapun tindakan instrumental yang ditunjukan oleh tokoh dalam novel tersebut memiliki keterkaitan sosial dengan lingkungan asli masyarakat. Tindakan dendam masih kita jumpai samapai sekarang di lingkungan kita.

Berlaku sewajarnnya

"Hari itu, tiga adik perempuan ku hanya diam di tempat duduknya masing-masing, sementara aku mondar-mandir menghabiskan rokok diteras rumah. Tak ada yang berusaha mencegah ibu, tak ada yang menangis, tak ada kata-kata perpisahan yang mengharuka. Kami semua ingin berlaku sewajarnya dan menunjukan aku tidak apa-apa (Madasari, 2017:17-18)."

Kutipan di atas menceritakan tentang hari dimana Ibu Jaya meninggalkan rumah karena sudah tidak bisa menahan sakit hati kepada bapak Jaya. ketiga adik Jaya hanya duduk diam sementara Jaya mondar mandi menghabiskan rokoknya. Saat Ibu Jaya pergi tak ada yang mencegahnya, tak ada yang menangis, tak ada kata-kata perpisahan yang mengharukan. Semua ingin berlaku wajar dan menunjukan bahwa Jaya dan ketiga adiknya tidak apa-apa. Tindakan yang dilakukan oleh tokoh di atas menandakan adanya tindakan instrumental. Hal ini dapat dibuktikan dengan sebelum melakukan suatu tindakan seseorang sadar akan apa yang dilakukan dan sadar akan tujuan dari tindakanya. Seperti tindakan Jaya dan ketiga adiknya yang tidak menunjukan sikaf apa-apa saat Ibunya pergi. Tindakan yang dilakukan mereka mempunyai tujuan. Agar Ibunya tidak merasa sedih saat meninggalkan anak-anaknya. Adapun tindakan instrumental yang ditunjukan oleh tokoh dalam novel tersebut memiliki keterkaitan sosial dengan lingkungan asli masyarakat. Tindakan wajar biasa orang tampakan saat ada masalah. Semua orang pasti pernah melakukan tindakan tersebut.

Mendekati

"Sambil menunggu operan bola, aku melihat mobil masuk ke kompleks sekolah. Mobil itu bergerak pelan, seperti sedang mencari sesuatu, hingga berhenti di tepi lapangan. Seseorang turun dari mobil menghampiri seorang anak di pingir lapangan. Bapak! Yang baru turundari mobil itu Bapak. Dia ada dihadapanku, dia datang ke rumah Ibu. Aku segera lari menghampirinya. Bukan karena aku ingin menemuinya tapi karena ingin tahu apa yang mau dilakukan Bapak di sini (Madasari, 2017:340).”

Kutipan di atas menceritakan Jaya yang sedang main bola bersama anak-anak kompleks madrasah. Ketika sambil menunggu operan bola Jaya melihat mobil masuk ke komplekan sekolah. Mobil itu berjalan pelan sampai tepi lapangan. Seseorang keluar dari mobil itu. Ternyata Bapak. Bapak menanyakan seseorang yang berada di lapangan. Melihat bapaknya Jaya langsung menghampirinya. Mencari tahu apa yang ingin Bapak lakukan di tempat Ibu. Tindakan yang dilakukan oleh Jaya menandakan adanya tindakan instrumental. Hal ini dapat dibuktikan dengan sebelum melakukan suatu tindakan seseorang sadar akan apa yang dilakukan dan sadar akan tujuan dari tindakanya. Seperti tindakan Jaya yang pergi menghampiri Bapaknya. Tujuan dari Jaya menghampiri Bapaknya adalah untuk mengetahui apa yang ingin Bapaknya lakukan. Tindakan Jaya mempunyai tujuan yang jelas. Adapun tindakan instrumental yang ditunjukan oleh tokoh dalam novel tersebut memiliki keterkaitan sosial dengan lingkungan asli masyarakat. Mendekati adalah tindakan yang dilakukan seseorang untuk menjumpai atau menghampiri orang yang ingin dituju. Tindakan yang kita lakukan hampir setiap hari.

Pergi

"Setelah perkelahianku dengan bapakku saat itu, aku memutuskan untuk pergi. Sudah tak ada lagi alasan buatku untuk tetap menghargainya sebagai bapak. Sudah tak sudi pula aku makan dari uang yang dihasilkannya. Kuliah kupun aku tinggalkan, karena aku sudah tak mau lagi bergantung pada 
Bapak. Aku ingin segera mandiri, menjadi manusia merdeka yang bias berdiri tegak sejajar dengan Bapak (Madasari, 2017:150)."

Kutipan di atas menceritakan tentang perkelahian Jaya dengan Bapaknya. Setelah berkelahi dengan Bapaknya dia memutuskan untuk pergi. Sudah tidak ada alasa untuknya tetap menghargai Bapaknya dan sudah tak sudi pula Jaya makan uang Bapaknya. Jaya tinggalkan kuliahnya, karena tidak mau bergantung pada Bapaknya. Jaya ungin segera mandiri, menjadi manusia merdeka yang bisa berdiri tegak sejajar dengan Bapaknya. Tindakan yang dilakukan oleh Jaya menandakan adanya tindakan instrumental. Hal ini dapat dibuktikan dengan sebelum melakukan suatu tindakan seseorang sadar akan apa yang dilakukan dan sadar akan tujuan dari tindakanya. Seperti tindakan Jaya memilih pergi meninggalakan rumah berhenti sekolah tujuannya karean ia sudah tidak mau bergantung pada orang tuanya ingin mandiri. Tindakan yang dilakukan Jaya mempunyai tujuan yang jelas. Adapun tindakan instrumental yang ditunjukan oleh tokoh dalam novel tersebut memiliki keterkaitan sosial dengan lingkungan asli masyarakat. Semua orang pasti pernah melakukan tindakan pergi. Tindakan itu bisa dilakukan oleh siapa aja dan kapan aja.

\section{Menuruti}

"Segera buat akun email mu sekarang. Tinggal ikuti saja itu petunjuknnya," katanya. Aku menuruti apa yang dikatakannya. Tak ada gunanya mendebatkan hal seperti ini. Lagipula ini cara terbaik untuk mengkhiri ketegangan dan ketersinggungan antara kami (Madasari, 2017:81)."

Kutipan di atas menceritakan tentang Jaya yang di suruh kekasihnya membuatkan email untuk mencari kerja. Jaya menuruti apa yang dikatakan kekasihnya. Lagi pula hanya itu cara terbaik untuk mengakhiri ketegangan dan ketersinggungan antara Jaya dan kekasihnya. Tindakan yang dilakukan oleh Jaya menandakan adanya tindakan instrumental. Hal ini dapat dibuktikan dengan sebelum melakukan suatu tindakan seseorang sadar akan apa yang dilakukan dan sadar akan tujuan dari tindakanya. Seperti tindakan Jaya yang menuruti perkataan kekasihnya untuk membuat emai. Tindakan yang dilakukan Jaya tujuanya untuk untuk mengakhiri ketegangan dan ketersinggungan antara Jaya dan kekasihnya dengan cara menuruti kata-kata kekasihnya. tindakan yang Jaya lakukan mempunyai tujuan yang jelas yaitu untuk mengakhiri perdebatan. Adapun tindakan instrumental yang ditunjukan oleh tokoh dalam novel tersebut memiliki keterkaitan sosial dengan lingkungan asli masyarakat. Setiap orang pasti penah menuruti perintah seseorang.

Menghilangkan ketegangan

"Ibu menuntunku pulang tampa bicara. Ia mengompres luka di wajah ku tampa berkata apaapa.

"Bapak batal jadi dekan, Bu," kataku. Aku ingin menghilangkan ketegangan. Aku juga tak mau melihat Ibu sedih hanya gara-gara aku berkelahi dengan Bapak.

"Alhamdulillah to," jawab Ibu datar.

"Tulisan Ibu di baca banyak orang, Bu," kataku lagi (Madasari, 2017:343)."

Kutipan di atas menceritakan tentang Ibu Jaya yang menuntun Jaya pulang setelah berkelahi dengan Bapaknya. Ibu Jaya menuntun dan mengompres luka di wajah Jaya tampa berkata apa-apa. Jaya tak mau Ibunya sedih dia berbica menghilangkan ketegangan. Berkata kepada Ibunya bahwa Bapaknya batal menjadi dekan. Tetapi ibunya hanya memjawab Alhamdulillah dengan nada yang datar. Jaya pun berkata lagi bahwa tulisan ibunya banyak yang baca. Karena Ibunya sempat berkata bahwa siapa yang akan membaca tulinanya. Tindakan yang dilakukan oleh Jaya menandakan adanya tindakan instrumental. Hal ini dapat dibuktikan dengan sebelum melakukan suatu tindakan seseorang sadar akan apa yang dilakukan dan sadar akan tujuan dari tindakanya. Seperti tindakan Jaya yang mengalihkan keteganggannya tujuanya agar Ibunya tidak sedih dan suasana bisa kembali norma. Tindakan yang dilakukan Jaya jelas mempunjai tujuan. Adapun tindakan instrumental yang ditunjukan oleh tokoh dalam novel tersebut memiliki keterkaitan sosial dengan lingkungan asli masyarakat. menghilangka ketegangan adalah tindakan yang dilakukan seseorang agar suasan kembali normal seperti biasa. Semua orang pasti pernah merasa suanana yang tegang.

Tak langsung mengetuk 
"Kamar Maera masih tertutup rapat saat aku samapai disana. Gordennya belum buka, tanda dia masih belum bangun. Aku tak langsung mengetuk, takut menggangu tidur Maera. Aku duduk di depan pintu, mengisap rokokku yang entah kenapa rasanya jadi tak seenak biasanya.

Jam tujuh pagi. Tetangga-tetangga kos Maera mulai keluar kamar untuk berangkat kerja. Mereka melirikku curiga. Aku mulai gelisah. Bukan karena takut pada pikiran orang, tapi takut terjadi apa-apa pada Maera. Tak biasanya dia belum bangun. Apakah dia sakit? Atau dia tak ada dikamarnya? Atau jangan-jangan...? (Madasari, 2017:348)."

Kutipan di atas menceritakan Jaya yang pergi ke Jakarta ketika melihat foto kekasihnya terpampang di jalan. Setiba di Jakarta kamar kekasih Jaya masih tertutuprapat. Gordennya belum buka, tanda kekasihnya masih blm bangun. Jaya tak langsung mengetuk kamar kekasihnya. karena takut menggangu tidur kekasihnya. jaya duduk di depan pintu kamar kekasihnya sambil mengisap rokoknya yang entah kenapa rasa rokoknya menjadi tak enak. Tepat jam tujuh tetangga koskekasihnya mulai keluar kamar untuk bekerja. Tetangga kos kekasihnya melirik Jaya dengan curing Jaya menjadi mulai gelisah bukan karena takun akan pemikiran anak-anak kos kekasihnya Maera tapi takut terjadi apa-apa pada kekasihnya. Tak biasa kekasihnya belum bangun. Jaya mulai berpikir macam -macam mengenai kekasihnya. Tindakan yang dilakukan oleh Jaya menandakan adanya tindakan instrumental. Hal ini dapat dibuktikan dengan sebelum melakukan suatu tindakan seseorang sadar akan apa yang dilakukan dan sadar akan tujuan dari tindakanya. Seperti yang dilakukan Jaya setiba di kos kekasihnya dia tak langsung mengetuk pintu kamarnya. Tujuan Jaya tak langsung mengetuk pintu kamarnya adalah taku menggangu tidur kekasihnya. tindakan yang dilakukan Jaya mempunyai tujuan yang jelas. Adapun tindakan instrumental yang ditunjukan oleh tokoh dalam novel tersebut memiliki keterkaitan sosial dengan lingkungan asli masyarakat. Tindakan mengetuk pintu pasti pernah kita lakukan.

Diam

"Tapi aku memilih diam. Aku tak ingin dia tahu bahwa Matajaya adalah aku. Aku tak ingin dia menertawakan setiap hal yang kukatakan kepada banyak orang karena ia tahu itu omong kosong belakang. Aku tak ingin Matajaya kehilangan wibawanya sedikit pun, termasuk dihadapan Maera (Madasari, 2017:225).”

Kutipan di atas menceritakan tentang Jaya yang memilih diam ketika di tanya kekasihnya nama facebook dan twiternya. Jaya tak ingin kebohongannya terbongkar. Tak mau kalau kekasihnya tau sebenarnya Matajaya adalah Jaya pacarnya sendiri. Jaya tak mau kekasihnya Maera menertawakan apa yang ia katakana kepada semua orang tentang kebohongan-kebohongan. Jaya tak ingin Matajaya kehilangan wibawanya sedikit pun meski di depan kekasihnya Maera. Tindakan yang dilakukan oleh Jaya menandakan adanya tindakan instrumental. Hal ini dapat dibuktikan dengan sebelum melakukan suatu tindakan seseorang sadar akan apa yang dilakukan dan sadar akan tujuan dari tindakanya. Seperti tindakan Jaya yang memilih diam ketika di tanya kekasih akun facebook dan tewiternya. Tujuan Jaya diam karena Jaya tidak mau kekasihnya tahu akun yang ia punya karena dia bercerita bohong kepada orang lain. Tindakan yang dilakukan Jaya mempunyai tujuan yang jelas. Adapun tindakan instrumental yang ditunjukan oleh tokoh dalam novel tersebut memiliki keterkaitan sosial dengan lingkungan asli masyarakat. Tindakan dengan berdiam sering kita lakukan dimana aja dan kapan aja sesuai suasana hari kita.

Memotong kata-kata

"Akardewa bilang aku perempuan yang punya kecerdasan dan keberanian luar biasa.

"Akardewa bilang, dunia baru butuh orang-orang seperti aku.

"Akardewa bilang......"

"Ah, dia selalu seperti itu pada semu orang! Aku memotong kata-katanya. Taktahan rasanya mendengar Maera bermanis-manis menyebut nama Akardewa (Madasari, 2017:240)."

Kutipan di atas menceritakan tentang Maera kekasih Jaya yang memuji-muji Akardewa di depan Jaya. Jaya tidak tahan mendengar kekasihnya bermanis-manis menyebut nama Akardewa di depanya. Ia memotong pembicaraan kekasihnya. agar kekasihnya berhenti memuji Akardewa. Tindakan yang dilakukan oleh Jaya menandakan adanya tindakan instrumental. Hal ini dapat dibuktikan dengan sebelum melakukan suatu tindakan seseorang sadar akan apa yang dilakukan dan sadar akan tujuan 
dari tindakanya. Seperti tindakan Jaya yang memotong pembicaran kekasinya. Tujuan Jaya memotong pembicaraan kekasinya adalah agar kekasihnya berhenti memuji-muji Akardewa di depan Jaya karna Jaya merasa cemburu. Tindakan yang di lakukan Jaya jelas mempunyai tujuan. Adapun tindakan instrumental yang ditunjukan oleh tokoh dalam novel tersebut memiliki keterkaitan sosial dengan lingkungan asli masyarakat. Tindakan dengan memotong kata-kata masih sering kita lakukan jika kita merasa bosan atau tidak senang dengan apa yang orang bicarakan.

Selalu berganti-ganti nomor HP

"Nomor HP-ku selalu berganti-ganti. Yang sekarang ku pakai baru kubeli dua minggu yang lalu. Aku selalu tak ingin gampang dicari. Dengan nomor HP yang terus berganti, hanya orang yang aku hubungi yang bias mencariku kembali." (Madasari, 2017:57)

Kutipan di atas menceritakan tentang Jaya yang selalu berganti-ganti nomor HP. yang sekarang dipakai Jaya baru dia beli dua minggu yang lalu. Karena dia selalu tak ingin gampang dicari. Dengan nomor HP yang terus dia ganti maka hanya orang yang ingin dia hubungilah yang bisa mencari dia kembali. Tindakan yang dilakukan oleh Jaya menandakan adanya tindakan instrumental. Hal ini dapat dibuktikan dengan sebelum melakukan suatu tindakan seseorang sadar akan apa yang dilakukan dan sadar akan tujuan dari tindakanya. Seperti tindakan Jaya yang selalu berganti-ganti nomor HP. Tujuanya agar tak ada yang bisa mencarinya dan hanya Jaya tng bisa menghubungkan orang. Tindakan yang di lakukan Jaya jelas mempunyai tujuan. Adapun tindakan instrumental yang ditunjukan oleh tokoh dalam novel tersebut memiliki keterkaitan sosial dengan lingkungan asli masyarakat. Tindakan dengan gonta-ganti nomor HP masih dilakukan sampai sekarang. apalagi pada anak-anak yang masih labil.

Menahan diri

"Saat posisinya agak jauh aku dengar ia berkata, "Dasar pengangguran. Sensitif! Makanya cari kerja sana. Biar punya harga diri. Biar nggak gampang emosi!"

Aku menahan diriku untuk mengejar dan menghajarnya. Bukan karena aku takut, tapi aku tak mau membuat kegaduhan di rumah kos ini. Pasti pemilik kos akan langsung mengusirku atau yang lebih apes lagi melaporkan ku kepada polisi. Urusanya akan panjang. Akan berbeda jika aku menghajar anak itu di jalanan. Tunggu ya, kapan-kapan kita jumpa di jalan aku buat babak belur kau! (Madasari, 2017:248)."

Kutipan di atas menceritakan Jaya yang emosi karena disinggung oleh tetangga baru kosnya. Sehingga Jaya menjadi marah karena dikatakana tidak punya harga diri karena tidak mempunyai pekerjaan. Sehingga Jaya ingin sekali menghajar tetangga barunya itu. Tapi Jaya menahan dirinya untuk tidak mengejar dan menghajarnya. Bukan karena Jaya takut, tapi Jaya tak mau membuat kegaduhan di rumah kos yang dia tinggali. Pasti pemilik kos akan langsung mengusir Jaya atau yang lebih apes lagi melaporkan Jaya kepada polisi. Urusanya akan panjang. Akan berbeda jika Jaya menghajar tetangga barunya itu di jalanan. Tindakan yang dilakukan oleh Jaya menandakan adanya tindakan instrumental. Hal ini dapat dibuktikan dengan sebelum melakukan suatu tindakan seseorang sadar akan apa yang dilakukan dan sadar akan tujuan dari tindakanya. Seperti tindakan Jaya dengan menahan dirinya untuk tidak mengejar dan menghajar tetangga barunya yang telah menghina dirinya. Tujuan jaya tidak menghajar tetangga barunya adalah karena dia tidak mau membuat kegaduhan yang membuat dirinya dalam masalah. Tindakan yang Jaya lakukan jelas mempunyai tujuan. Adapun tindakan instrumental yang ditunjukan oleh tokoh dalam novel tersebut memiliki keterkaitan sosial dengan lingkungan asli masyarakat. Menahan diri adalah tindakan yang masih kita lakukan sampai sekarang. Takut

"Aku meningalkan Facebook Nura begitu saja. Tak kutinggalkan jejak apapun dicerita panjangnya itu. Tentu saja aku juga tak pernah menyebarkan cerita itu. Aku terlalu takut menentang arus. Aku takut berdiri sendiri, dikucilkan, lalu ditinggalkan. Baru saja aku memulai hidup baru di sini. Apakah semua akan kuhancurkan begitu saja? (Madasari, 2017:140).”

Kutipan di atas menceritakan Jaya yang meninggalkan facebook Nura setelah mendengar semua ceritanya. Jaya meninggalkan facebook Nura begitu saja. Tak sedikitpun Jaya tinggalkan jejak di cerita Nura yang panjang itu yang Nura keritakan pada dia. Jaya juga tidak pernah menyebarkan cerita Nura yang di ceritakan ke dia. Jaya terlalu takut menentang arus. Jaya takut berdiri sendiri, dikucilkan, 
lalu ditinggalkan. Baru saja Jaya memulai hidup baru di sini. Apakah semua akan Jaya hancurkan begitu saja. Tindakan yang dilakukan oleh Jaya menandakan adanya tindakan instrumental. Hal ini dapat dibuktikan dengan sebelum melakukan suatu tindakan seseorang sadar akan apa yang dilakukan dan sadar akan tujuan dari tindakanya. Seperti tindakan Jaya yang meninggalkan facebook Nura setelah mendengar ceritanya yang panjang. Tujuan dari tindakan Jaya adalah karena dia takut dikucilkan ditinggalkan pada dunia yang baru dia jelajahi. Tindakan yang dilakukan Jaya jelas mempunyai tujuan. Adapun tindakan instrumental yang ditunjukan oleh tokoh dalam novel tersebut memiliki keterkaitan sosial dengan lingkungan asli masyarakat. takut adalah tindakan yang sering rasakan seseorang saat melakukan sesuatu.

Pengikut setia

"Aku tak rela melita Juwita tak bahagia. Ia tak boleh ditertawakan teman-temannya. Ia tak boleh berkecil hati karena tak banyak mendapat perhatian. Maka aku pun menjadi pengikut setianya, member jempol pada semua foto dan kata-katanya, membelanya saat ia beradu pendapat dengan temanya, tampa tahu bahwa Matajaya adalah kakaknya. Aku yakin ini cara terbaik untuk menjaganya tampa berkurang sedikit pun kebebasannya (Madasari, 2017:173)."

Kutipan di atas menceritakan tentang Jaya yang tak rela melihat adik bungsunya tak bahagia. Dia tak mau adiknya di tertawakan oleh teman-temanya. Adiknya tak boleh berkecil hati karena tak banyak mendapatkan perhatian. Maka Jaya pun menjadi pengikut setia adaiknya yang selalu member jempol pada foto dan kata-kata yang di tulisadiknya. Selalu membelanya saat adiknya beradu pendapat dengan temanya tampa adiknya tahu bahwa Matajaya adalah kakaknya. Jaya jakin ini cara terbaik untuk menjaga adiknya tampa mengurang sedikitpun kebebasannya. Tindakan yang dilakukan oleh Jaya menandakan adanya tindakan instrumental. Hal ini dapat dibuktikan dengan sebelum melakukan suatu tindakan seseorang sadar akan apa yang dilakukan dan sadar akan tujuan dari tindakanya. Seperti tindakan Jaya yang menjadi pengikut setia adiknya. Tujuan Jaya menjadi pengikut setia adaiknya karena dia tak ingin adiknya sedih, di tertawakan dan di kucilkan temanya karena kurang ada yang member jempol pada foto dan kata-katanya. Tindakan yang dilakukan Jaya jelas mempunyai tujuan. Adapun tindakan instrumental yang ditunjukan oleh tokoh dalam novel tersebut memiliki keterkaitan sosial dengan lingkungan asli masyarakat. Tindakn itu masik kita rasakan samapai sekarang.

Memutuskan untuk pulang

"Akhirnya aku memutuskan pulang. Aku ingin melihat apa yang terjadi disana. Aku ingin ikut menemui Juwi. Lagi pula Ibu yang tahu kabar ini dari TV terus menghubungiku sepanjang hari. Saking kesalnya aku tadi sempat berkata, "Kenapa Ibu tidak pulang saja dan melihat sendiri bagaimana keadaan Juwi? (Madasari, 2017:181).”

Kutipan di atas menceritakan tentang Jaya memutuskan pulang kerumahnya setelah mengetahui adik bungsunya di laporkan oleh gurunya ke polisi. Jaya ingin melihat apa yang terjadi di rumahnya. Jaya ingin ikut menemui adiknya. Lagi pula Ibu Jaya yang mengetahui kabar dari TV terus menghubunggi Jaya sepanjang hari. Seking kesalnya Jaya pada Ibunya Jaya sempat berkata kepada Ibunya kenapa tidak pulang dan melihat sendiri keadaan adiknya. Tindakan yang dilakukan oleh Jaya menandakan adanya tindakan instrumental. Hal ini dapat dibuktikan dengan sebelum melakukan suatu tindakan seseorang sadar akan apa yang dilakukan dan sadar akan tujuan dari tindakanya. Seperti Jaya yang memutuskan pulang setelah mengetahui adiknya di laporkan ke polisi. Tujuan Jaya pulang kerumahnya adalah untuk melihat dan mengetahui apa yang terjadi pada adiknya. Tindakan yang dilakukan Jaya jelas mempunyai tujuan. Adapun tindakan instrumental yang ditunjukan oleh tokoh dalam novel tersebut memiliki keterkaitan sosial dengan lingkungan asli masyarakat. Tindakan memutuskan untuk pulang adalah tindakan yang masih dilakukan

Mengalihkan perhatian

"Apa lagi kalau bulan membebaskan ayahku dari dalam penjara?" ia balik bertanya dengan tatapan tajam. Seketika aku mengalaihkan pandanganku. Ada yang menakutkan dalam sorot mata Kara. Sesuatu yang berkobar dan menjilat-jilat, siap menyambar dan membakar apa pun yang disekitarnya. Aku kerap lupa, Kara ada karena dendam. Kara adalah kumpulan luka dan trauma. Dibalik senyum 
manis dan tawanya, ada amarah yang sewaktu-waktu bias membakar musuh-musuhnya. Dibalik usia yang masih belasan, ada jiwa yang matang dalam penantian.

"Mamamu pergi ke mana, Kar?" aku mengalihkan perhatian.

"Biasa..” jawabnya sambil tetap menatap layar di hadapanya."Nengok Papa (Madasari, 2017:285)."

Kutipan di atas menceritakan tentang pembicaraan antara Jaya dan Kara. Kara sahabat Jaya merasa sulit untu membuat mama Kara percaya akan internet padahal dengan internet Kara bisa dengan mudah mengeluarkan Bapaknya dari penjara. Seketika Jaya mengalaihkan pandangannya. Ada yang menakutkan dalam sorot mata sahabatnya Kara. Sesuatu yang berkobar dan menjilat-jilat, siap menyambar dan membakar apa pun yang disekitarnya. Jaya kerap lupa, Kara sahabatnya ada karena dendam. Kara sahabatnya adalah kumpulan luka dan trauma. Dibalik senyum manis dan tawanya, ada amarah yang sewaktu-waktu bias membakar musuh-musuhnya. Dibalik usia yang masih belasan, ada jiwa yang matang dalam penantian. Akhirnya Jaya mengalihkan pembicaraan dengan menanyakan Ibu Kara yang sedang pergi. Tindakan yang dilakukan oleh Jaya menandakan adanya tindakan instrumental. Hal ini dapat dibuktikan dengan sebelum melakukan suatu tindakan seseorang sadar akan apa yang dilakukan dan sadar akan tujuan dari tindakanya. Seperti tindakan Jaya yang mengalihkan pembicaraan sahabatnya Kara. Tujuan Jaya mengalihkan perhatian karena merasa takut melihat sorot mata sahabatnya itu. Tindakan yang dilakukan Jaya jelas mempunyai tujuan. Adapun tindakan instrumental yang ditunjukan oleh tokoh dalam novel tersebut memiliki keterkaitan sosial dengan lingkungan asli masyarakat. mengalihkan pembicaraan adalah tindakan yang sering kita lakukan agar orang tidak tersinggung.

Kembali

"Aku tinggalkan kamar itu tampa menutup kembali pintunya. Diam-diam aku berharap Maera akan mengejarku, memintaku kembali, lalu kami akan kembali menjalani hari-hari kami seperti sebelumnya. Tapi hingga aku sampai di jalan besar, Maera tak juga memanggilku. Aku menoleh kebelakang berharap siapa tau Maera berdiri disana tapi merasa gengsi memanggil lebih dulu. Tak ada siapa-siapa. Aku kembali berjalan menuju kos, siapa tahu Maera berdiri di depan pagar menungguku kembali. Tapi samapi didepan pagar aku tak melihat siapa-siapa. Pintu kamar sudah ditutup, lampunya sudah mati. Aku memilih pergi, kembali kejalan besar. Bukan karena gengsi tapi karena tak yakin Maera masih mau menerima ku kemabali (Madasari, 2017:295)."

Kutipan di atas menceritakan Jaya yang sedang bertengan dengan kekasihnya. Jaya meninggalkan kamar kekasihnya tampa menututupnya kembali. Diam-diam Jaya berharap kekasihnya mengejar, memintaknya kembali, lalu Jaya dan kekasihnya akan kembali menjalani hari-hari seperti sebelumnya. Tapi hingga Jaya sampai di jalan besar, kekasihnya Maera tak juga memanggilnya. Jaya menoleh kebelakang berharap siapa tau kekasihnya Maera berdiri disana tapi merasa gengsi memanggilnya lebih dulu. Jaya kembali berjalan menuju kos, siapa tahu kekasinya Maera berdiri di depan pagar menunggunya kembali. Tapi samapi di depan pagar dia tak melihat siapa-siapa. Pintu kamar kekasihnya sudah tertutup, dan lampunya sudah mati. Akhirnya Jaya memilih pergi. Bukan karena gengsi tapi karena tak yakin kekasihnya Maera masih mau menerimanya kemabali. Tindakan yang dilakukan oleh Jaya menandakan adanya tindakan instrumental. Hal ini dapat dibuktikan dengan sebelum melakukan suatu tindakan seseorang sadar akan apa yang dilakukan dan sadar akan tujuan dari tindakanya. Seperti tindakan Jaya sengaja tidak menutuk kamar kekasihnya saat dia keluar kamar. Tujuannya agar kekasihnya menarik dan membawanya kembali ke kamar. Tindakan yang dilakukan Jaya jelas mempunyai tujuan. Adapun tindakan instrumental yang ditunjukan oleh tokoh dalam novel tersebut memiliki keterkaitan sosial dengan lingkungan asli masyarakat. Tindakan kembali masih kita lakukan samapai sekarang.

Tindakan Rasionalitas Nilai

Tindakan rasionalitas nilai adalah tindakan yang dialkukan telah melalui pertimbangan yang matang dan mempunyai tujuan yang jelas, yang membedakanya terletap pada niali-nilai yang menjadi dasar dalam tindakan ini. Nilai-nilai tersebut dapat berupa nilai agama, hukum, moral dan bisa juga nilainilai lain yang menjadi keyakinan disetiap individu masyarakat. 
Nilai agama

"Ibu juga selalu rajin mengirim SMS. Hingga SMS terakhirnya dua hari yang lalu, ia masih tak tahu aku sudah tak tinggal di rumah lagi. Ia juga tak tahu aku sudah tak kuliah lagi. SMS-nya selalu bertabur doa dan harapan, seperti: ibu doakan kuliah mu lancer. Semoga lulus lalu dapat kerja yang baik. Saat hatiku sedang senang, aku pun langsung membalas SMS itu dengan singkat: Amin!" (Madasari, 2017:169)."

Kutipan di atas menceritakan tentang Jaya selama di Jakarta. Selama Jaya di Jakarta Ibu selalu rajin mengirimkan SMS yang berisi nasehat dan doa kepada Jaya. Ibu masih tidak tahu kalau Jaya sudah berhenti kuliah. Ibu selalu menasehati Jaya agar rajin kuliah, mendoakan Jaya cepat selesai kulian. SMS ibu Jaya balas jika hati sedang senang dan jika dalam suasana hati yang tidak baik Jaya lebih memilih membaca dan tidak membalas SMS dari Ibunya. Tindakan yang dilakukan oleh tokoh di atas menandakan adanya tindakan rasionalitas nilai. Hal ini dapat dibuktikan dengan tindakan yang dilakukan seseorang atas dasar nilai . Seperti tindakan yang dilakukan bu Jaya untuk Jaya anaknya. Ibu Jaya dengan sabar menasehati dan selalu mendoakan anaknya yang sedang jauh dari dirinya. Nilai yang menjadi dasar Ibu Jaya melakukan tindakanya adalah nilai agama. Adapun tindakan rasionalita nilai yang ditunjukan oleh tokoh dalam novel tersebut memiliki keterkaitan sosial dengan lingkungan asli masyarakat. Setiap orang pasti mempunyai agama. Kita semua memiliki kepercayaan masingmasing yang dimana disebut agama.

Nilai budaya

"Setiap pagi aku berangkat sekolah bersama Bapak. SMP-ku sekat dengan kampus tempatnya mengajar. Saat jam pulang sekolah, Bapak kembali menjemputku dan mengantar aku pulang, lalu segera berangkat lagi tak lama kemudian. Tiga adikku yang masih duduk di bangku SD tak jauh dari rumah sudah lebih dahulu tiba di rumah. Tak lama kemudian Ibu pulang dari tempatnya mengajar. Aku habiskan waktuku di dalam rumah. Menonton televise, bermain video game, mengerjakan PR, dan menuruti perintah ibu untuk tidur siang (Madasari, 2017:26)."

Kutipan di atas menceritakan tentang Jaya yang berangkat sekolah bersama Bapaknya. Karena SMP Jaya dekat dengan kampus tempatnya mengajar Bapaknya. Saat jam pulang sekolah, Bapak Jaya akan kembali menjemput Jaya dan mengantar Jaya pulang, lalu Bapaknya segera berangkat lagi. Tiga adiknya Jaya yang masih duduk di bangku SD tak jauh dari rumah sudah lebih dahulu tiba di rumah dari pada Jaya. Tak lama kemudian Ibu Jaya pulang dari tempatnya mengajar. Jaya selalu habiskan waktunya di dalam rumah. Menonton televise, bermain video game, mengerjakan PR, dan menuruti perintah ibunya untuk tidur siang. Tindakan yang dilakukan oleh tokoh di atas menandakan adanya tindakan rasionalitas nilai. Hal ini dapat dibuktikan dengan tindakan yang dilakukan seseorang atas dasar nilai . Seperti tindakan yang dilakukan Jaya sebagai seorang anak mematuhi semua aturan dan perintah orang tuanya. Nilai yang menjadi dasar Jaya melakukan tindakanya adalah nilai budaya. Adapun tindakan rasionalita nilai yang ditunjukan oleh tokoh dalam novel tersebut memiliki keterkaitan sosial dengan lingkungan asli masyarakat. Budaya adalah suatu cara hidup yang dikembangkan dan dimiliki bersama sebuah kelompok orang dan diwariskan dari kenerasi ke generasi. Nilai moral

"Ibu adalah semesta pertamaku. Ia orang pertama yang mengajariku berpura-pura. Ia membetulkan kata-kata yang aku ucapkan dan meminta ku untuk menggantinya dengan kata-kata lain yang lebih pantas. Ia tak mau ku sapa dengan "kamu". Baginya itu kata yang tidak sopan untuk menyapa orang tua. Sesekali aku lupa dan tetap bertanya padanya, "kamu sudah makan?" ibu melotot kepada ku (Madasari, 2017:18).”

Kutipan di atas menceritakan Ibu Jaya adalah semesta pertama Jaya. Dia orang pertama yang mengajari Jaya berpura-pura. Dia membetulkan kata-kata yang Jaya ucapkan dan meminta Jaya untuk menggantinya dengan kata-kata lain yang lebih pantas. Dia tak mau Jaya sapa dengan "kamu". Bagin Ibu Jaya kata kamu tidak sopan untuk menyapa orang tua. Sesekali Jaya lupa dan tetap bertanya pada Ibunya menggunakan kata kamu. Maka ibu Jaya melotot matanya kepada Jaya. Tindakan yang dilakukan oleh tokoh di atas menandakan adanya tindakan rasionalitas nilai. Hal ini dapat dibuktikan dengan tindakan yang dilakukan seseorang atas dasar nilai. Seperti tindakan yang dilakukan Ibu Jaya 
dengan memelototi matanya ketika Jaya memanggilnya dengan sebutan kamu dan Jaya harus merubah pagilannya menjadi Ibu. Panggilan kamu untuk orang tua sangat tidak sopan. Tindakan yang dilakukan oleh jaya tidak sopan. Nilai yang menjadi dasar Jaya melakukan tindakanya adalah nilai moral. Adapun tindakan rasionalita nilai yang ditunjukan oleh tokoh dalam novel tersebut memiliki keterkaitan sosial dengan lingkungan asli masyarakat. Moral adalah tindakan manusia yang memiliki nilai positif atau negatif. Kita semua manusia yang bermoral yang bisa membedakan mana yang baik dan mana yang Jahat.

\section{SIMPULAN}

Berdasarkan analisis data dengan pendekatan sosiologi sastra yang dilakukan terhadap novel Kerumunan Terakhir karya Okky Madasari, maka peneliti dapat menarik kesimpulan mengenai tindakan sosial dalan novel Kerumunan Terakhir karya Okky Madasari, adalah sebagai berikut.

1. Tindakan tradisional adalah tindakan yang dilakukan oleh seseorang karena mengikuti tradisi atau kebiasaan yang sudah diajarkan secara turun temurun dan telah baku serta tidak dapat diubah lagi. Dari penelitian ini, peneliti menemukan 8 kutipan yang berhubungan dengan tindakan tradisional.

2. Tindakan afeksi adalah tindakan yang dipengaruhi oleh emosi seseorang tidak melalui pertimbangan yang sadar tindakan ini tercipta dengan spontan karena pengaruh emosi. Dari penelitian ini, peneliti menemukan 30 kutipan.

3. Tindakan instrumental adalah tindakan yang didasarkan atas pertimbangan dan pilihan yang sadar akan tujuan yang ingin dicapainya. Dari penelitian ini, peneliti menemukan 28 kutipan.

4. Tindakan rasionalitas nilai adalah tindakan yang dilakukan telah melalui pertimbangan yang matang dengan mempunyai tujuan yang jelas. yang membedakannya terletak pada nilai-nila yang menjadi dasar dalam tindakan tersebut. Nilai-nilai tersebut dapat berupa nilai budaya, nilai agama, dan nilai moral, serta niali-nilai lain yang menjadi keyakinan disetiap indipisu masyarakat. Dari penelitian ini, peneliti menemukan 19 kutipan.

\section{SARAN}

Saran yang disampaikan peneliti berdasarkan hasil penelitian sebagai berikut.

1. Kepada penbaca atau masyarakat diharapkan tetap menjaga tindakan kita saat melakukan interaksi sosial dengan orang lain karena tindakan sosila berpengaruh bagi orang lain dan diri sendiri serta menghindari perilaku-perilaku negatif yang tidak patut untuk ditiru.

2. Kepada guru hendaknya memberikan variasi dalam proses pembelajaran sastra agar peserta didik dapat lebih kritis dalam mengapresiasikan sebuah karya sastra dan memberikan pengalaman belajar yang baru bagi peserta didik.

\section{Daftar Pustaka}

Anwar, Yesmil dan Adang. (2013). Sosiologi Untuk Universitas. Bandung: Refika Aditama.

Madasari, Okky. (2017). Kerumunan Terakhir. Jakarta: Gramedia Pustaka Utama.

Moleong, LJ. (2017). Metodologi Penelitian Kualitatif. Bandung: Remaja Rosdakarya.

Siswantoro. (2016). Metode Penelitian Sastra. Yokyakarta: Pustaka Pelajar.

Sugiyono. (2015). Metode Penelitian Kombinasi: Mixed Methods. Bandung: Alfabeta.

Susanto, H., \& Santoso, B. W. J. (2017). Wujud Peralihan Kode dalam Peristiwa Tutur Informal Masyarakat Multietnis di STKIP Singkawang Kalimantan Barat Jurnal Pendidikan Bahasa dan Sastra Indonesia, 2, 26-30.

Wellek Rene \& Austin Warren. (2014). Teori Kesusastraan. Jakarta: Gramedia Pustaka Utama. 